\title{
Perancangan Kendali Motor Listrik Berbasis Smart Relay (Zelio)
}

\author{
Mohammad Yudi Irawan \\ Program Studi Teknik Elektro, Fakultas Teknik \\ Universitas Trunojoyo Madura Jl. Raya Telang \\ Bangkalan Jawa Timur 69162 \\ Email : irawanyudi325@gmail.com
}

\begin{abstract}
Abstrak - Pesatnya perkembangan teknologi menjadikan pekerjaan manusia lebih mudah. Salah satunya pengendalian putaran motor, pengendalian putaran motor awalnya menggunakan relay yang disusun menjadi rangkaian relay. Dalam penelitian ini, dirancang sebuah kendali motor 3 phase "Forward and Reverse” berbasis smart relay ZELIO. Rangkaian terdiri dari sebuah smart relay Zelio SR2B121JD, 1 buah power supply $12 \mathrm{~V}, 2$ buah kontaktor, 2 buah MCB, 3 buah tombol, dan 3 buah lampu indikator. Penggunaan smart relay untuk pengendali utama berdasarkan pertimbangan penelitian sebelumnya yang dapat mengefesiensi penggunaan relay konvensional. Pada penelitian ini dilakukan proses simulasi pada aplikasi zeliosoft sebelum kemudian dilakukan percobaan pada alat yang telah dibuat, hal ini diharapkan mampu meminimalisir terjadinya error. Dalam simulasi indikator lampu forward akan menyala ketika motor berputar ke arah kanan begitu pula dengan indikator reverse. Sedangkan ketika indicator forward dan reverse dalam keadaan mati maka indicator standby akan menyala, namun ketika salah satu saja indikator forward atau reverse yang menyala makan status standby akan mati.

Kata Kunci- Zelio, MCB, Controller
\end{abstract}

\section{PENDAHULUAN}

Berdasarkan dari data maupun pengalaman praktikum dan hasil observasi selama praktikum, peneliti menemukan berbagai masalah yang berhubungan prasarana yang mendukung 3 proses kegiatan belajar mengajar maupun saat praktik."Seperti peralatan praktik yaitu komponen PLC (Progammable Logic Control) yang masih belum dibentuk sebuah media Trainer-kit PLC (Progammable Logic Control), tetapi digunakan untuk praktik oleh praktikan dalam pelajaran Instalasi Motor Listrik. Dalam Proses Praktik Instalasi Motor Listrik timbul berbagai masalah diantaranya": kesalahan pengawatan, rusaknya salah satu port I/O PLC (Programable Logic Control) ,baut yang sudah kendor,"pemborosan pemakaian kabel instalasi, waktu pelajaran yang berjalan tidak efektif, praktikan kurang tertarikan pada saat proses belajar"mengajar atau praktikinovasi..

\section{BAHAN DAN METODE}

Dalam proses penelitian ini terdapat beberapa tahapan proses yang dilakukan sebelum dilanjukan ke proses perancangan sistem. Berikut ini merupakan flowchart metodologi.

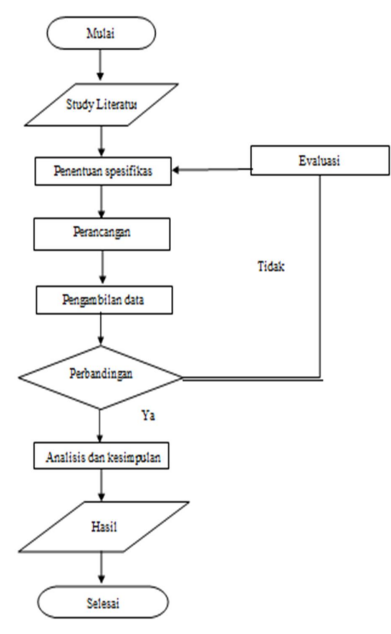

Gambar 1. Flowchat Penelitian

Pada penelitian ini dimulai dari perancangan ladder diagram, diagram ladder yang sudah ada maka dibuat rangkaiannya dan diberi beban berupa motor listrik yang bisa dikendalikan dengan forward/reverse

1. Sumber listrik 3 fasa merupakan komponen utama dalam penelitian ini, digunakan sebagai supply daya utama pada perancangan alat.

2. MCB daya/ 3 fasa digunakan sebagai pembatas daya atau sebagai pengaman beban berlebih (overload) dan hubung singkat (short circuit) yang mana dalam instalasinya menggunakan 3 fasa R/S/T. Sedangkan MCB 1 fasa hanya menggunakan salah satu fasa sebagai pengontrol.

3. Zelio merupakan controller dalam penelitian ini yang mana segala program pada alat ini berada pada zelio ini

4. Kontak forward dan kontak reverse terhubung dengan MCB fasa dan zelio, hal ini sebagai pengunci. Kontaktor forward sebagai normally open sedangkan kontaktor reverse sebagai normally closed sebagai pengaman.

5. Motor 3 fasa sebagai output dari 3 fasa

6. PB stop yaitu push button stop untuk menghentikan proses

7. PB forward yakni push button yang digunakan untuk melanjutkan atau meneruskan proses 
8. PB reverse yaitu push button yang digunakan untuk mengunci proses

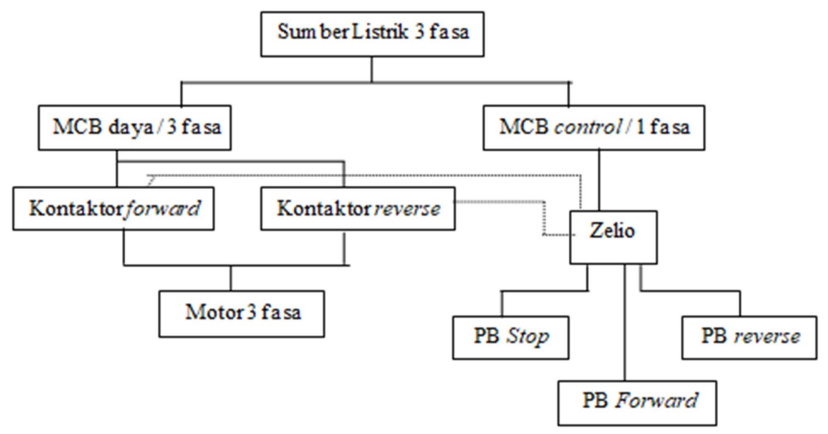

Gambar 2. Blok diagram sistem

Rangkaian kontrol memiliki tiga komponen utama yaitu block Zelio SR, block kontaktor dan panel kendali. Ketiga komponen saling berhubungan dan dikordinasi oleh Zelio SR sebagai perangkat kontrol berbasis PC. Zelio SR yang digunakan bertipe SR2 B121FU yang memiliki 4 terminal output dan memiliki tegangan kerja $220 \mathrm{~V}$.

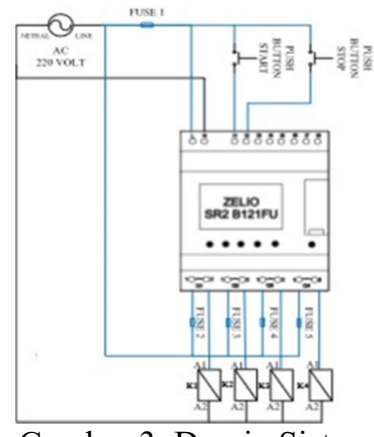

Gambar 3. Desain Sistem

III. HASIL DAN PEMBAHASAN

1. Pengujian perancangan sistem

Pada penelitian menggunakan PLC Zelio.

A. Simulasi pada software

Pada gambar di bawah merupakan tampilan awal aplikasi

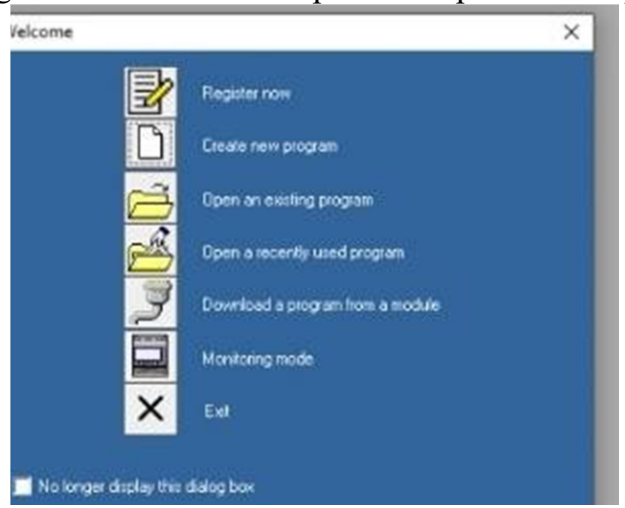

Gambar 4. Simulasi 1

Pada gambar di bawah dapat dilihat ketika $P B$ forward ditekan tanpa distop degan menekan $P B$ Stop maka indikator lampu Q2 tetap aktif, untuk menyalakan indikator lampu Q1 ditekan PB Stop dahulu.

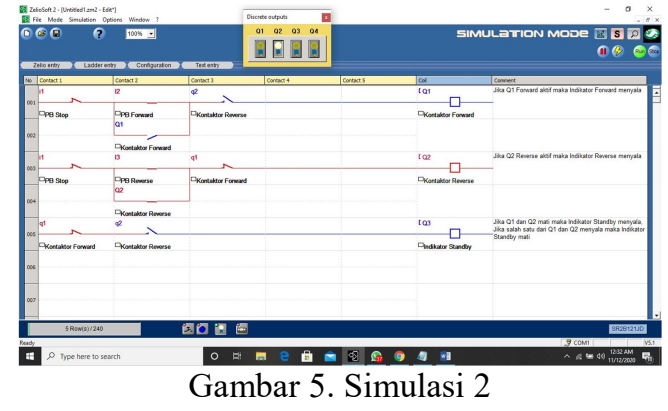

B. Pengujian Alat

Pada gambar di bawah ini dapat dilihat foto sebelum rangkaian dinyalakan

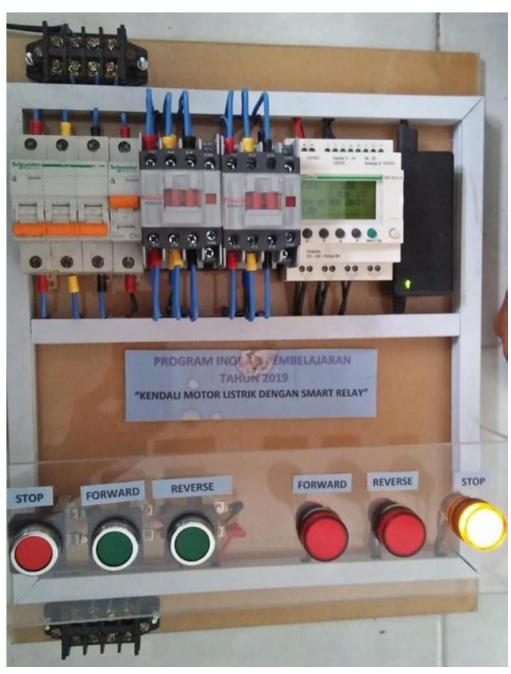

Gambar 6. Uji Coba Kontrol Forward Reverse

Pada gambar di bawah menampilakan foto ladder diagram yang dibuat didalam Zelio

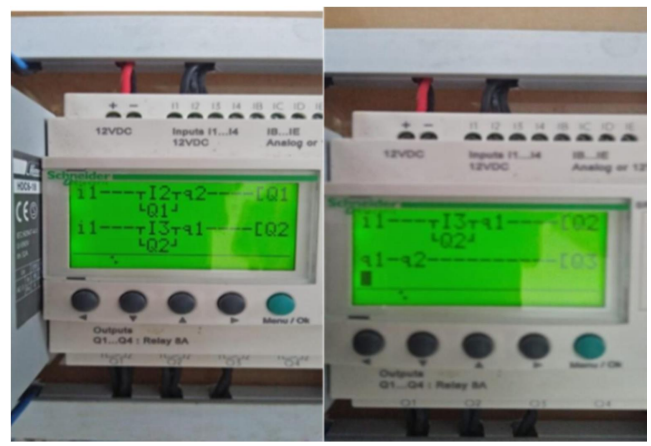

Gambar 7. Pengujian Zelio

Pada gambar 8. Menampilkan foto dari kiri mcb daya 3 fasa, mcb control 1 fasa, kontaktor forward, kontaktor Reverse, modul Zelio, dan power supply. 


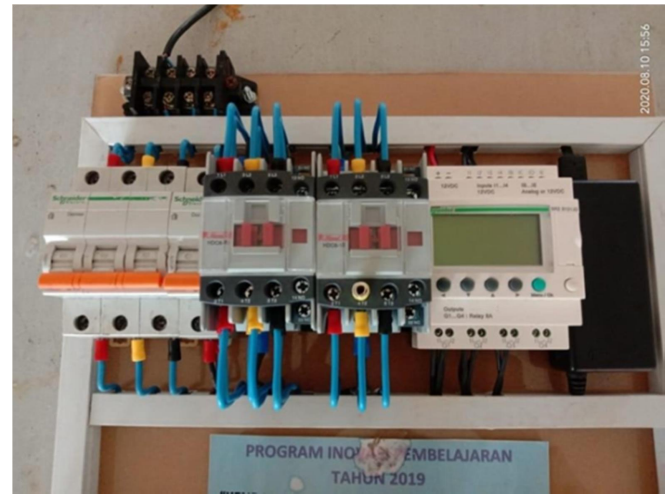

Gambar 8. Pengujian MCB daya MCB Conrol Kontraktor

\section{KESIMPULAN}

Berdasarkan hasil perancangan dan uji coba maka dapat diambil kesimpulan yaitu:

1. Perencanaan awal sangat diperlukan untuk melancarkan tahapan-tahapan dalam pelaksanaan pembuatan alat. Hal ini dilakukan untuk efisiensi waktu dalam perancangan alat.

2. Dengan adanya alat mampu meningkatkan produktivitas di kelas industri, karena cukup sederhana dalam kontruksinya dan mampu diandalkan, seperti yang diketahui hampir 90\% energi mekanik yang digunakan dalam industri disediakan oleh motor 3 fasa.
Dengan adanya alat ini memungkinkan untuk dilakukan pemrograman ataupun pengontrolan secara jarak jauh REFERENSI

[1] S. Na, "Pengendalian generator dan pompa pengendali banjir menggunakan plc zelio sr2b201fu," vol. 1, no. 24, pp. 115-125, 2015.

[2] M. Imron, "Rancang Bangun Sistem Pencuci Kendaraan Berbasis Plc Zelio Type Sr2B121Jd," J. Tek., vol. 7, no. 1, pp. 68-76, 2018, doi: 10.31000/jt.v7i1.953

[3] M. Suhendar et al., "Rancangan Smart Relay Zelio Pada Pengoperasian Pompa Air Bersih Gedung Bertingkat," vol. 4, no. 2, pp. 29-37, 2017.

[4] B. M. Farid, M. Mukhsin, and F. Rofii, "Pengaturan Regulator Autotrafo 3 Phasa Berbasis Mini Plc Zelio," Widya Tek., vol. 26, no. 2, pp. 145-157, 2018, doi: 10.31328/jwt.v26i2.790.

[5] R. Fairuzza, T. Sukmadi, and J. Windarta, "Perancangan Mesin Amplas Kayu Menggunakan Motor Induksi 3 Fasa dengan Zelio Logic Smart Relay,” Transient, vol. 6, no. 4, pp. 675-682, 2017.

[6] N. HUDA and T. RIJANTO, "Pengembangan Modul Pembelajaran Smart Relay Pada Mata Pelajaran Instalasi Motor Listrik Di Smk Negeri 5 Surabaya," J. Pendidik. Tek. Elektro, vol. 7, no. 3, pp. 3-8, 2018.

[7] Pramono Aditya, "Pendeteksi logam berbasis plc ( programmable logic control ) dengan sistem pneumatik pada konveyor," Pendeteksi Logam Berbas. Plc (Programmable Log. Control. Dengan Sist. Pneum. Pada Konveyor, pp. 1-7, 2013.

[8] A. Ahyar, M dan Zulkarnain, "Rancang bangun media praktikum sistem pneumatik berbasis plc," Ranc. Bangun Media Prakt. Sist. Pneum. Berbas. Plc, vol. 03, pp. 219-228, 2016.

[9] A. A. Rafiq, "Optimalisasi Smart Relay Zelio sebagai Kontroler Lampu dan Pendingin Ruangan,” J. Teknol. Elektro, vol. 8, no. 2, pp. 95-100, 2017.

[10] A. Kusmantoro and A. Nuwolo, "Pengendali Star Delta Pada Pompa Deep Well 3 Fasa 37 Kw Dengan Plc Zelio Sr3B261Fu," vol. 8, no. 2, pp. 1-11, 2015.

[11] A. Romadlan, "Rancang Bangun Sistem Monitoring Lampu Jalan berbasis Internet of Things (IoT) menggunakan Arduino Mega 2560," pp.370-375,2019. 